
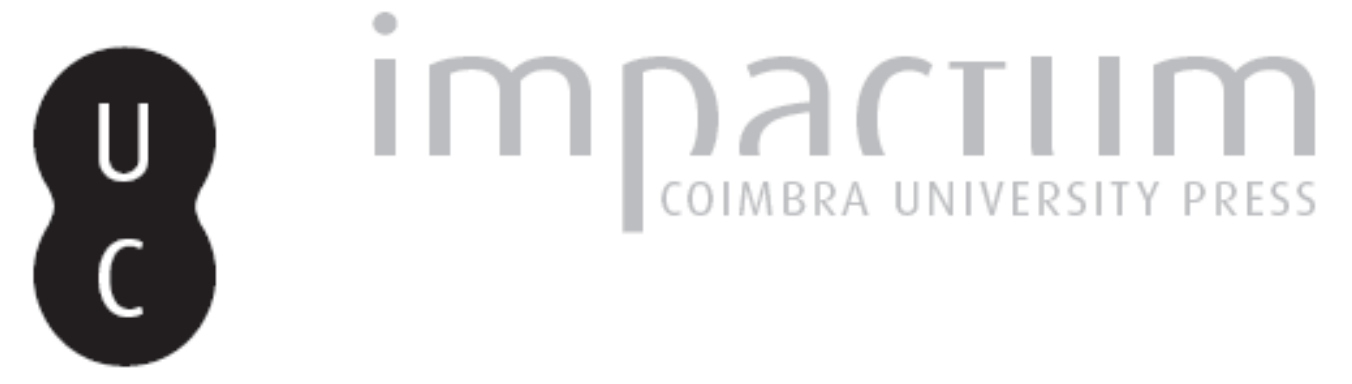

\title{
Narração e Storytelling em Mysterious Object at Noon, de Apichatpong Weerasethakul
}

\author{
Autor(es): Bértolo, José \\ Publicado por: Centro de Literatura Portuguesa \\ URL \\ persistente: \\ URI:http://hdl.handle.net/10316.2/30063 \\ DOI: \\ DOI:http://dx.doi.org/10.14195/2182-8830_1-2_4
}

Accessed : $\quad$ 26-Apr-2023 11:45:22

A navegação consulta e descarregamento dos títulos inseridos nas Bibliotecas Digitais UC Digitalis, UC Pombalina e UC Impactum, pressupõem a aceitação plena e sem reservas dos Termos e Condições de Uso destas Bibliotecas Digitais, disponíveis em https://digitalis.uc.pt/pt-pt/termos.

Conforme exposto nos referidos Termos e Condições de Uso, o descarregamento de títulos de acesso restrito requer uma licença válida de autorização devendo o utilizador aceder ao(s) documento(s) a partir de um endereço de IP da instituição detentora da supramencionada licença.

Ao utilizador é apenas permitido o descarregamento para uso pessoal, pelo que o emprego do(s) título(s) descarregado(s) para outro fim, designadamente comercial, carece de autorização do respetivo autor ou editor da obra.

Na medida em que todas as obras da UC Digitalis se encontram protegidas pelo Código do Direito de Autor e Direitos Conexos e demais legislação aplicável, toda a cópia, parcial ou total, deste documento, nos casos em que é legalmente admitida, deverá conter ou fazer-se acompanhar por este aviso.

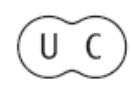




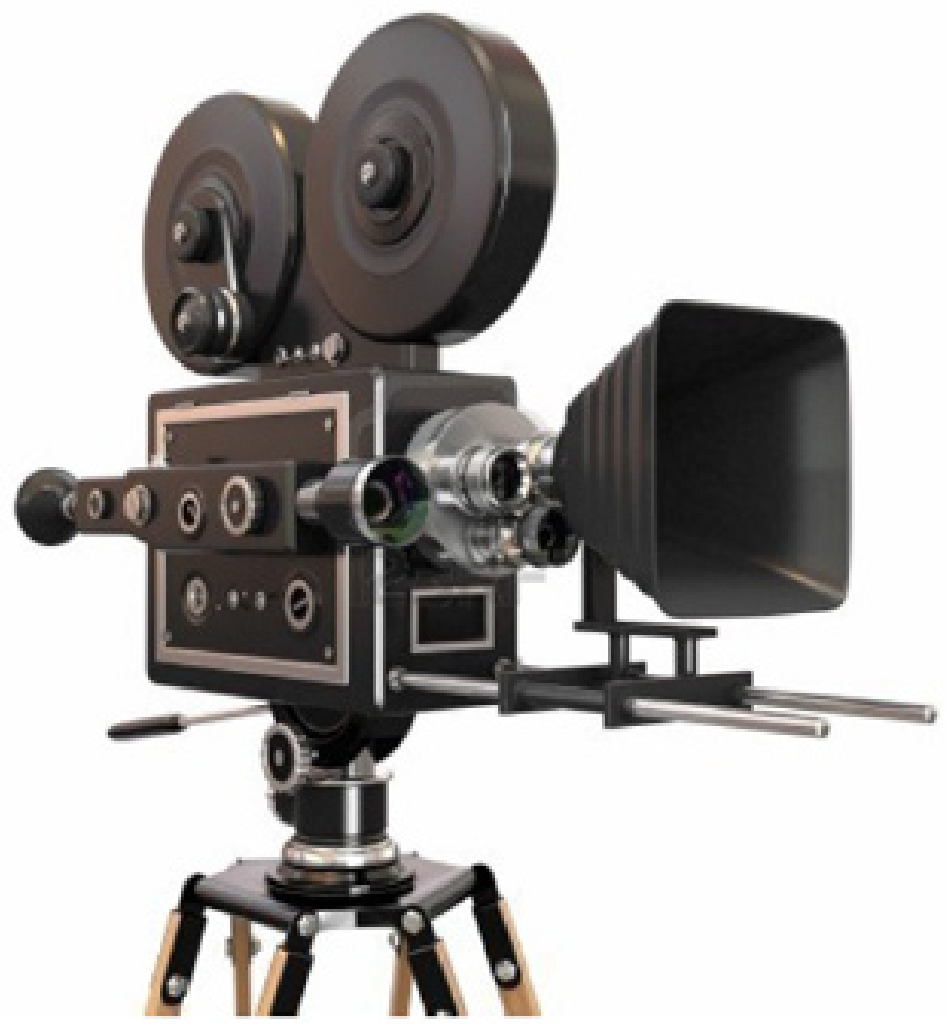

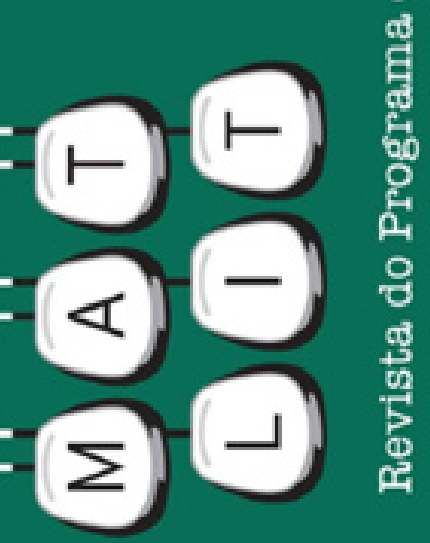

Vol. 1.2 (2013)

ISSN 2182-8830

'Escrita e Cinema'

Osvaldo Manuel Silvestre

\& Clara Rowland (orgs.) 


\title{
Narração e Storytelling em Mysterious Object \\ at Noon, de Apichatpong Weerasethakul JOSÉ BÉRTOLO \\ Centro de Estudos Comparatistas | Universidade de Lisboa
}

\begin{abstract}
Resumo
Este texto propõe uma leitura de Mysterious Object at Noon (Apichatpong Weerasethakul, 2000), considerando questões de narração suscitadas pelo lugar central que $\mathrm{o}$ ato de storytelling ocupa no filme. Equacionam-se problemas tais como a ausência de texto prévio (argumento) e a atribuição de ordem ao filme pela narração oral, in loco, como se este se escrevesse à medida que vai sendo contado. Atentar-se-á em como, estruturando-se deste modo, o filme reflete sobre a especificidade do cinema enquanto máquina narrativa. Palavras-chave: Cinema; Argumento; Narrativa; Narração; Storytelling; Oralidade.
\end{abstract}

\section{Abstract}

This essay is a close analysis of Mysterious Object at Noon, directed by Apichatpong Weerasethakul, in which are considered questions of narration motivated by the central place the act of storytelling holds in the film structure. Problems such as the nonexistence of a script and the way the film seems structured by oral narration, in loco, as if the film were being written as it is told, will be analyzed. Finally, I describe how, through this structure, the film reflects upon the specificity of cinema as a way of telling/showing stories. Keywords: Film; Script; Narrative; Narration; Storytelling; Orality.

It all began with the first storyteller of the tribe. Italo Calvino, "Cybernetics and Ghosts"

ysterious Object at Noon $(M O A N)$ começa com um intertítulo
em que se lê: "Once upon a time..." Ao abrir com estas palavras
e não com imagens, o filme parece propor-se como um objecto em que a linguagem (aqui escrita, mais tarde também falada) é fundamental. A abrangência da expressão fixa "once upon a time" possibilita uma infinidade de aposições, o que faz com que esta frase, para além de apontar para o potencial narrativo da linguagem (sabemos que, por definição, todas as histórias começam com um "once upon a time"), aponte também para a infinidade de possibilidades que o modo narrativo permite. Neste primeiro momento, em que há apenas um "once upon a time", qualquer história pode surgir. Não interessará então tanto, em $M O A N$, atentar na história apresentada, como na problematização que o filme põe em prática do próprio ato de contar e da aparente "vocação narrativa" que a linguagem 
carrega, que se expressa de maneira paradigmática em expressões como a escolhida para este início.

Deste modo, por um lado, todo o filme constituirá uma reflexão sobre a utilização da linguagem oral e escrita na criação e partilha de narrativas, por outro - e mais importante -, será uma exploração do cinema enquanto um meio em que, devido à sua especificidade audiovisual, a linguagem e outros elementos se articulam na criação e apresentação de narrativas. Em suma, trata-se da problematização do cinema enquanto máquina narrativa, um meio que, segundo André Gaudreault:

is a seemingly more complex narratological object than textual or staged narrative, and this is because it is the product of a combination of the narrative possibilities of the other two. More precisely, it is the product of a linking of the two basic modes of narrative communication: narration and what I call monstration. (Gaudreault, 2009: 7)

O filme de Weerasethakul é enformado numa estrutura que, numa primeira abordagem, poderíamos aproximar das framed stories medievais de Giovanni Boccaccio (Il Decameron) ou Geoffrey Chaucer (The Canterbury Tales), obras fortemente influenciadas pela tradição oral, constituídas por um primeiro nível diegético em que várias personagens se reúnem para contar histórias que dão origem a novos níveis: "histórias dentro da história" (cf. Lothe, 2000: 32-34). Em $M O A N$, no entanto, e como se verá, a "história dentro da história" é apenas uma, embora contada por diferentes narradores.

$\mathrm{Na}$ introdução de The Essay Film: From Montaigne, After Marker, Timothy Corrigan refere o filme de Weerasethakul como exemplo de "filme ensaio", não especificando, no entanto, o assunto que o filme ensaia. Talvez seja então útil entender este texto como uma reflexão sobre $M O A N$ enquanto filme que ativamente ensaia o potencial narrativo do cinema, inserindo-se assim no subconjunto de "filmes ensaio" que Corrigan explora no último capítulo do seu estudo, "About Refractive Cinema: When Films Interrogate Films". Para tal, propomos uma leitura progressiva do filme, de sequência narrativa em sequência narrativa, atentando no modo como nele insistentemente se problematizam, através deste dispositivo, questões de storytelling, de narração e da especificidade narrativa do cinema.

O primeiro plano é em travelling para a frente, residindo a câmara no interior de uma viatura em movimento. A figura do movimento caracterizará $M O A N$, pois o seu desenvolvimento comprova-o como filme metamórfico no género, nas formas, na viagem pela Tailândia e nas narrativas informes e resquícios de narrativas com que se constrói. Acompanhando a imagem, há música que parece ser extradiegética, mas que se prova diegética no momento em que uma voz começa a resumir os episódios anteriores de um folhetim radiofónico. Surge neste programa de rádio o primeiro ato de narração oral, 
ainda antes de surgir o genérico do filme. O melodrama é, depois, substituído por um anúncio publicitário de incensos, que dá lugar a anúncios de venda de peixe. O que rapidamente é revelado, no entanto, é que os anúncios de venda de peixe não provêm da emissão radiofónica - conforme se suporia -, mas de uma voz vinda de dentro da viatura, pertencente a um homem que a câmara mostra logo a seguir, a falar para um microfone. Neste prólogo, as expectativas do espectador são repetidamente goradas, e este constitui um padrão que o filme seguirá com diferentes configurações.

Está-se no interior da carrinha do peixe com uma mulher. O seu olhar dirige-se ora para alguém junto da câmara, ora para a câmara, denunciando a presença do aparelho que grava, e quebrando assim a ilusão da ficção: neste momento, o espectador pode afirmar, com legitimidade (embora não com inteira certeza), estar perante um documentário.

A mulher entrevistada, visível em campo, conta a sua história. Michel Chion chamou "'récit non iconogène" (récit qui ne génère pas d'images)" (Chion, 2007: 274) a este tipo de estratégia, em que uma personagem em campo conta uma história que não ativa nova imagem, possibilitando o filme acesso ao sujeito que enuncia, i.e., ao ato de enunciação (ou, neste caso, mais especificamente de storytelling), e à mesma estratégia chamou Avrom Fleishman "dry narration" (Fleishman, 1992: 25). A opção, numa primeira fase, por uma construção deste tipo põe em relevo o próprio acontecimento (bappening) do "contar". "I didn't know how to ride then. I always vomited" é, depois do que se pôde ouvir no programa radiofónico, a primeira fala que se ouve, uma fala que, significativamente, contém informação suficiente para dar início a uma história: inclui o pronome "I", que identifica o narrador como personagem pertencente à narrativa, e "then", que situa a história temporalmente (ainda que numa temporalidade incerta - saber-se-á tratar-se da infância). Da narrativa melodramática radiofónica (vinculado a um objeto tecnológico e a uma voz desvinculada de um corpo $^{1}$ ) passa-se para a narrativa autobiográfica. Após a narração que a mulher faz da sua história de vida, alguém da equipa de filmagens lhe pergunta: "Now, do you have any other stories to tell us. It can be real or fiction." Este momento é importante na caracterização da especificidade do filme enquanto documentário. É o momento em que se reforça o rompimento com a ilusão da quarta parede, ao ouvir-se o cineasta fora de campo a falar, a interpelar o actante e a intimá-lo a contar uma nova história - o ato de direção/manipulação é evidenciado, como se o filme estivesse a ser costurado (contado, escrito) perante o testemunho do espectador. Supor-se-ia que o resto do filme poderia seguir o mesmo padrão: uma equipa viaja pela Tailândia rural e recolhe testemunhos de indivíduos que comprovem uma tese de implicações sociais ou políticas

1 Trata-se do que Michel Chion identificou como "voz acusmática": "La situation d'écoute acousmatique est celle où l'on entend le son sans voir la cause dont il provient" (Chion, 2003: 411). 
acerca do país. O caminho por que envereda Apichatpong Weerasethakul é, no entanto, como se verá, diferente. O filme acabará por se revelar mais como sendo sobre cinema do que sobre as pessoas comuns que entrevista, portanto, mais "filme ensaio autorreflexivo" do que "documentário social".

Após a interpelação, há um corte para um novo espaço com novos corpos em campo, o de um rapaz numa cadeira de rodas e o de uma mulher. Trata-se do domínio da ficção a irromper no filme que parecia ser, até então, documental: a "história dentro da história", ou o "filme dentro do filme". No entanto, a mudança na banda de imagem não é acompanhada por uma alteração da banda de som, que se prolonga sobre a imagem discordante. Sobre estas novas imagens, inicia-se a narração em voice over pela mulher: "Let's say there was a house. There was a disabled boy and a teacher who came to teach him every day." A sua voz, antes vinculada a um corpo visível, funciona agora como a voz radiofónica inicial, acusmática, sobre imagens outras. As imagens então mostradas pela câmara surgiram, no entanto, antes do início da narração oral, como se ativadas não pela narração propriamente dita, mas pela imaginação da mulher que, durante breves segundos antes do corte na montagem, parecia pensar na história a contar; como se, antes de se lembrar do que dizer, formasse uma imagem mental à qual o cinema dá corpo (imagem fílmica) e sobre a qual, depois de materializada em linguagem, se diz (narração oral). O que o cinema estabelece, ao transformar esta narrativa oral/linguística em imagem/filme, é uma tentativa de cristalização de uma narrativa textual em imagem, traduzindo-se, essencialmente, num processo de adaptação/metamorfose que o filme normalmente estabelece com um material linguístico que lhe antecede, nomeadamente, o guião. Quando esta mulher conta a história do rapaz e da sua professora, está a fornecer o guião que Weerasethakul transforma em filme (dentro do filme); a estas situações, em que a narração num primeiro nível diegético origina novo nível, Fleishman denomina de "enactements" (Fleishman, 1992: 25). O que se encena, então, é um processo distinto do filme que "adapta” um guião préexistente: aqui, a narrativa visual sobrepõe-se ao "guião oral", num processo de "tradução simultânea". Assim, não é despiciendo que um dos primeiros elementos fornecidos de caracterização de personagens seja que o rapaz porque preso a uma cadeira de rodas - não podia ver o mundo exterior, pelo que a professora lhe trazia fotografias desse mundo ao qual ele não tinha acesso: tal como as fotografias, nessa narrativa, funcionam como intermediário (artificial) entre o rapaz e um mundo que está para além do que os seus olhos podem ver, também o filme torna visível o que uma narração (oral ou escrita) não possibilita ver.

Após a cessação da voz, em campo continua a ser mostrado o "filme de ficção" do rapaz, sem que haja mudança na banda de som, isto é, a certa altura já não se ouve a voz da mulher, mas os ruídos do envolvente que, com a ausência de voz, ganham relevo. Quando o rapaz fala - e uma vez que não há acesso ao som diegético dessa ficção (por enquanto, só imagem, como 
filme mudo) -, não é possível ouvi-lo, pelo que se recorre a um novo intertítulo que contém a sua fala: "What did you do in the outside world today?", evidenciando novamente o artifício da construção. Após esta pergunta, tem lugar um flashback, ainda nesse segundo nível diegético, em que que se vê a professora num mercado, e que corresponde à resposta à pergunta do rapaz. Aqui, no entanto, não há acesso à voz da professora, mas a uma encenação dos "eventos reais" que funciona como adaptação desse discurso (/guião) a que não temos acesso (p. ex.: "fui ao mercado, comprei uns chinelos, etc."). Esta ação, que se sabe contada no plano diegético pela professora, não é narrada, mas sim mostrada pelo filme (com som diegético, síncrono); surge aqui o primeiro momento em que $M O A N$ adota um modelo comum de cinema de ficção, mostrando simplesmente as coisas a acontecer. Apesar disto, logo de seguida surge novo intertítulo, quebrando essa pretensa ilusão de transparência: "'Then I had my hair done,' the teacher says."

Neste ponto, verifica-se já que até a mera dimensão narratológica dos intertítulos parece equacionada no filme, porque neles parecem confluir várias vozes. No intertítulo inaugural supõe-se a existência de uma voz omnisciente; o segundo intertítulo - no plano do filme dentro do filme consistia na transcrição da fala de uma personagem ("What did you do in the outside world today?"); o terceiro contém a fala de uma personagem comentada por uma voz narradora, voz essa que tanto poderia corresponder à voz omnisciente do primeiro intertítulo como à voz da mulher que ativou esta ficção. Poderia este parecer um excurso, porém lembremos que, no respeitante à narração, tudo em $M O A N$ parece ser pormenorizadamente construído. Para mais, o cinema mudo constitui, pela sua especificidade ontológica (nomeadamente pelo necessário recurso ao texto), uma área privilegiada para os estudos narratológicos em cinema. Sobre a proficuidade do mudo para o estudo narratológico do cinema, escreve Fleishman:

It was intertitles, however, that became the prevailing narrational intrument in Western cinema. Nondialogue intertitles state time, place, and context, make introductions, transitions, and conclusions, summarize character's mental and moral states, motives, and so on. Going beyond these primary, though by no means self-evident, narrational functions are other of a more subtle influence $[\ldots]$ the intertitles' all-knowing fiats induce a narrator-effect even when an individual source is not stated. (Fleishman, 1992: 31)

A cena seguinte, uma conversa entre uma médica e um paciente mais a sua filha, contém um cruzamento de tipos de discurso. Tendo sido já antes estabelecida a dificuldade de audição do pai, dá-se uma troca entre pai e médica em que o primeiro adota um discurso narrativo e a segunda um discurso expositivo, intercalados. O que daqui resulta é um não-diálogo, porque o pai parece não ouvir a sua interlocutora, limitando-se a narrar. Por 
outro lado, a médica executa um monólogo, porque o seu interlocutor não a ouve, e portanto a exposição não é apreendida - não há comunicação. Num filme sobre a narração e sobre as modalidades do trânsito de narrativas, esta cena parece funcionar como a antítese do modo como o filme se posiciona perante as narrativas que testemunha e faz testemunhar. A sua posição perante estas é ativa: o filme "ouve" as histórias, apreende-as e reprodu-las, sendo essa reprodução uma possibilidade de resposta (por fixação e perpetuação) às mesmas, efetuando-se assim uma espécie de diálogo entre filme, actantes (narradores reais) e espectador. Aquilo a que se assiste nesta cena é, contrariamente a esse processo, histórias que não têm recetores, e portanto não se perpetuam, desaparecendo no próprio momento em que são contadas.

O "filme dentro do filme" vai-se desenrolando de uma maneira aparentemente autónoma até ao momento em que a voz da mulher que iniciara a história se volta a sobrepor à imagem: "while they were studying, the teacher, her name is Dogfahr. She left for a restroom." Se a narração é feita no passado - "they were" - a atribuição do nome no presente - "her name is Dogfahr" - perturba a coesão do mecanismo narrativo, numa coexistência de temporalidades à partida impossível. No entanto, devido ao facto de a especificidade da linguagem cinematográfica possibilitar o acompanhamento no presente da narração ocorrida num tempo passado (ela diz "they were studying", mas o espectador está a vê-los a estudar, porque a situação do cinema acontece sempre no presente - todos os tempos são "contemporaneizados"), esta incoerência narrativa não adquire o peso, enquanto "erro", que teria se somente ouvida ou lida; afinal, esta história, por estar a ser "cinematizada", não tem necessariamente de obedecer às regras linguísticas do modo narrativo, mas unicamente às das possibilidades da linguagem cinematográfica. A respeito destas possibilidades de narrar em cinema, note-se que as regras da ilusão da ficção cinematográfica são também quebradas no momento seguinte, quando a narração pára, a professora sai de campo (tal como a narração ditara) e ouve-se a seguir, sem corte na imagem: "How many bottles do you need?", fala que não vem do "filme dentro do filme" que se está a ver nesse momento, mas da instância documental na qual ocorre um diálogo que o espectador do filme ouve, enquanto vê na imagem o rapaz sozinho. Se previamente o desfasamento entre som e imagem já era assinalável, quando a voz, embora independente da imagem, a acompanhava (narrando), aqui - quando a narrativa veiculada pelo som é inteiramente independente da narrativa que a imagem mostra - a cisão é ainda mais marcada, extremando a artificialidade da sua relação. Sem corte aparente na banda de som, a narração volta: "then he became suspicious. Why there was no word from his teacher", uma fala irónica, se se atentar que, durante estes momentos em que o rapaz sozinho no quarto "não ouvia palavra", o 
espectador ouviu várias vozes sem corpo, portanto muitas e inesperadas palavras.

Mais tarde, após novo surgimento de vozes provenientes da instância real da narradora, esta continua a narração, num processo de descrição que corresponde perfeitamente ao que se vê em campo ("he tried to open the door", quando a câmara o mostra a tentar abrir a porta; "he dragged her into the room", quando a câmara o mostra igualmente). Poderia evocar-se uma figura análoga à do bensht ${ }^{2}$, mas aqui, no entanto, está-se perante um filme que existe sobre a oralidade, porque por ela ativado, contrariamente ao benshi, cuja vOz é irremediavelmente subordinada ao filme (comenta o filme, informa acerca dele, inventa diálogo que o sirva, mas não o produz).

O primeiro segmento da ficção dentro do filme é finalizado no momento em que o rapaz vê um objeto a sair da saia da mulher e a rolar pelo chão. Aqui, se se atentar no discurso da narradora, percebe-se que esta está a construir a sua narrativa ao ritmo do pensamento, ou seja, sem tempo de reflexão prévio, algo latente no ritmo entrecortado do discurso, típico de quem não sabe precisamente o que dizer ("he... He saw... He saw an object rolling out from her skirt.”). O segmento narrado por esta primeira narradora termina com uma frase ("that was very strange") que não está longe do tipo de estratégias (neste caso, o cliffhanger) usadas no romance-folhetim a que o filme aludiu no início. Aqui chegados, compreendemos melhor a referência a esse universo de folhetins e seriados, uma vez que também ele foi, ao longo dos últimos dois séculos, um meio particularmente profícuo de questionação das formas narrativas populares: se os folhetins de Eugène Sue, por exemplo, contribuiram para as metamorfoses do romance ao longo do século XIX, os serials de Louis Feuillade (Fantômas; Les vampires; Judex) foram fulcrais para o estabelecimento do modelo narrativo no cinema da década de 1910.

A partir deste momento - tendo ficado estabelecido que $M O A N$ se constrói em dois vetores, um primeiro, documental, e um segundo, ficcional (ativado no documental, e portanto vinculado a este) - o desenvolvimento do filme será um prolongamento mais ou menos próximo desta anunciada estrutura: na dimensão documental, a equipa de filmagens prosseguirá a viagem pelo país, interpelará indivíduos, e pedir-lhes-á que continuem a ficção iniciada pela primeira actante, e disso resultará uma ficção que é encenada pelo filme e intercalada, na sua macroestrutura, com as partes documentais, sempre uma acompanhando a outra, porque indissociáveis.

Este método não só se aproxima da estrutura folhetinesca, como explora a possibilidade da prática do cadavre exquis em cinema, um cadavre exquis em que a autoria de cada pedaço de narrativa é mediada pelo dispositivo fílmico. Se no cadavre exquis literário é a materialidade do suporte que fixa as

2 "The benshi were [japanese] theatrical performers, present in the movie house $[\ldots]$ they supplied not only narrative information and commentary but also dialogue, in the absence of intertitles" (Fleishman, 1992: 30). 
contribuições de cada participante (contribuições físicas: cada indivíduo inscreve no papel a sua contribuição, e é esse o seu gesto autoral), no caso do cinema essa fixação é mais complexa. Por um lado, o cinema dá a ouvir um cadavre exquis oral, e neste caso o gesto autoral é dos narradores que contam; por outro lado, o filme traduz esse cadavre exquis oral em imagem, fixando-o na (i)materialidade do filme sempre que "cinematiza" o que no cadavre exquis se conta (e neste caso o gesto já não é dos narradores). O que se verifica é que, quando o filme não permite o acesso à ficção pela voz dos narradores, mas por essa tradução da narrativa oral para matéria fílmica (de que é exemplo a supracitada cena do mercado), não temos acesso à totalidade do cadavre exquis oral, mas a uma reconstituição em diferido (o "filme dentro do filme"), o que, tendo em conta o modelo do cadavre exquis literário, é problemático precisamente porque neste caso o gesto de fixação é o do filme, e dos autores da narração é-o apenas em segundo nível. Se o cinema é, por definição, um meio de representação em que não há ação física, direta, de um indivíduo sobre um objeto que produza um fim (como na literatura, em que o indivíduo escreve, e o produto artístico final é dependente quase unicamente desse processo), mas em que tudo é mediado pela tecnologia (câmara, montagem, projeção, etc.), o cadavre exquis - enquanto confluência de autorias várias e bem demarcadas - talvez seja impossível, porque no cinema nunca há um gesto autoral (de um indivíduo) que fixe e finalize a obra.

A segunda narradora é uma mulher idosa. Um membro da equipa de filmagens pergunta-lhe se o misterioso objeto com que se finalizou o segmento anterior (que para o espectador de $M O A N$ é um segmento fílmico, mas para ela é apenas uma narrativa oral ${ }^{3}$ ) poderia ser um rapaz. Ela responde afirmativamente, e parte daí para a construção de uma nova (/prolongamento da mesma) ficção em que o objeto misterioso do segmento anterior é revelado como sendo, afinal, um rapaz. Após a narração, observase a mulher a contar que um vizinho seu era visitado pela noiva morta durante a noite. Este discurso é, como o discurso inicial da anterior mulher, respeitante ao mundo real; no entanto, se o tom da "história real" da primeira narradora era marcadamente realista, o tom desta nova "história respeitante ao mundo real" é fantástico: embora se suponha que a noiva, por estar morta, não poderia ter visitado de facto o homem durante a noite, esta história é narrada como se fosse verídica. Deste modo torna-se evidente a íntima relação entre o narrador e o narrado. É, portanto, sintomático que o segmento da "história dentro da história" narrado pela primeira mulher seja, tal como o seu testemunho, fortemente naturalista, e que o segmento narrado

\footnotetext{
${ }^{3}$ Como se verá mais tarde no filme, o método utilizado terá sido o de gravar as vozes dos narradores e dá-las a ouvir aos seguintes, de modo a que possam continuar a história.
} 
pela segunda narradora seja fantástico, quando até a "história real" desta o é. Se no primeiro caso temos uma mulher "vitimada pela vida", com pais ausentes (o que tem reflexo, intui-se, na deficiência da criança e ausência de progenitores, resultando numa espécie de filme de "realismo social"), neste segundo há uma mulher porventura enlouquecida que produz uma narrativa ficcional (e consequentemente um "filme dentro do filme") imaginativa e fantástica ${ }^{4}$.

O segmento seguinte, proveniente da narração de um grupo de adolescentes, insere o tropo do mistério - típico de histórias de suspense - na narrativa. Depois de a professora ter morrido no final do primeiro segmento, assiste-se agora, no plano da ficção, ao surgimento da professora perante o rapaz, e então o espectador do filme fica naturalmente tão espantado com o acontecimento quanto o rapaz, por não possuir ainda o conhecimento da matéria que a narração dos adolescentes oferecerá momentos depois: aquela não é a professora real, mas um segundo rapaz metamorfoseado em professora. Isto constitui uma inversão de expectativas que deriva da estruturação (pela montagem) do filme, e que vai para além da questão da "cinematização da narração". Trata-se de uma espécie de jogo que se estabelece exclusivamente com o espectador do filme, que revela - através desta simples exibição de imagem que, sem acompanhamento de narração, não faz sentido no esquema de coerência da narrativa que vem sendo apresentado - o poder que o filme detém de manipular tanto a narrativa fornecida pelos actantes, quanto a apreensão dessa narrativa pelo espectador. Em última análise, o que o filme mostra não é o que os actantes contam, mas o que ele pretende mostrar: o gesto de autoria supremo é o do filme enquanto "great image-maker" (Gaudreault, 2007: 5), máquina geradora de imagens, sons e sentidos.

As pequenas narrativas "reais" continuam a pontuar $M O A N$. Ouve-se, a certa altura, um adolescente dizer: "for the best, I would like to go to Bangkok to find a job", numa expressão de um desejo que encerra em si potencialidades narrativas que, aliás, terão seguimento na dimensão ficcional do filme, quando as personagens se mudarem efetivamente para Banguecoque e lá arranjarem emprego.

\footnotetext{
${ }^{4}$ Esta problematização das relações possíveis entre narrador e narrado é característica de textos e filmes alicerçados na forma da frame story e no motivo do storytelling. Chaucer, por exemplo, explora este fenómeno de modo particularmente eficaz em The Canterbury Tales. Nesta obra, cada personalidade conta uma história distinta das restantes, no que diz respeito à temática e ao estilo. A propósito disto, lê-se numa introdução à obra: "[t]he idea of a collection of tales diversified in style to suit their tellers and unified in form by uniting the tellers in a common purpose is Chaucer's own" (Coghill, 2003: xvi), algo que, aliás, e com as necessárias modificações, poderia ser dito a propósito do filme de Weerasethakul.
} 
O que se segue à porção de filme reservada ao grupo de adolescentes perturbará a estrutura relativamente simples atrás enunciada. Este segmento é iniciado com um grande plano de um rádio que transmite as narrações previamente ouvidas, e depois a câmara executa um travelling que mostra um grupo de pessoas a ouvir o rádio (cf. nota 3). Uma nova volta do jogo diegético surge quando se ouve: "the neighbor came upstairs and saw Dogfahr, the teacher lying in the closet", porque esse momento então narrado já havia sido, pouco tempo antes, mostrado, sem que então o espectador pudesse identificar a identidade do homem que tirava a mulher do armário, aqui revelado como o vizinho. E a narração prossegue para além do que havia sido mostrado antes, enquanto a câmara mostra não o narrador, não a "cinematização" da narrativa, mas as pessoas que, então, ouvem a narração através do rádio. Neste momento, o espectador de $M O A N$ não só ouve a narração ao mesmo tempo que essas pessoas, como as vê a ouvir, num reforço da complexificação da experiência plurissensorial que o dispositivo fílmico proporciona. Ouve-se: "he helped her out of the closet. And woke her up. But he didn't know if she's the real teacher. My story is not really connected", consistindo este num novo momento de particular relevância nas dinâmicas de narração estabelecidas ao longo do filme. A narradora diz "my story is not really connected" quando adquire a consciência súbita de que a sua narração perdeu coerência na progressão temática: o vizinho nunca poderia não saber se aquela era a professora real, porque na sua mundividência não havia o conhecimento necessário para se poder questionar sobre se aquela mulher era a real ou a sua dupla, pelo que teria forçosamente de encará-la como verdadeira. O erro em que incorre a narradora é confundir a informação que ela (narradora omnisciente, fora da diegese) possui com o conhecimento necessariamente limitado das personagens da história que ela conta. Ela acrescenta: "I just made it up in an instant", expondo o problema que é, sob o ponto de vista da narração, contar uma história de modo automático, sem atentar na sua coerência interna, necessária à sua correta progressão num encadeamento contínuo e lógico de ações.

Depois disto, um membro da equipa pede ao grupo que continue a história. Como resposta, uma mulher propõe dois desenvolvimentos possíveis - este um equacionamento de possibilidades de continuação por parte de quem conta que ainda não havia sido mostrado em $M O A N$. Neste momento, há um corte para uma nova situação, em que se vê um espaço que funciona como palco, onde tem lugar uma representação teatral. Vê-se uma mulher que interrompe a representação para apresentar a sua personagem: "I am the fake teacher Dogfahr". Para além de se tratar do momento em que os planos documental e ficcional (i.e., a "história" e a "história dentro da história") coexistem mais ativamente no filme até ao momento, com a representação da narrativa ficcional no plano do documentário, entra uma vOz narradora omnisciente a comentar a ação, numa clara interpelação ao 
espectador, num intertítulo em que se lê: "Remember? She is in fact the mysterious boy." Momentos depois, acaba o espetáculo, os atores juntam-se à boca de cena e a câmara mostra finalmente, através de um travelling, o público que assistia à peça a aplaudir, enquanto os atores fazem vénias e dizem: "the end". Este "the end" pode ser entendido como "final da peça", mas também como - atentando na macroestrutura do filme e nas analogias possíveis que temos vindo a identificar - final do/da segmento/narrativa/ volume de folhetim/parte de cadavre exquis/sequência de filme.

Seguidamente, surge uma cena de ficção que repete uma outra anterior, que aparecera então isolada, não explicada, e portanto desvinculada de sentido no esquema narrativo fornecido. Saber-se-á adiante que essa se tratava de uma espécie de prolepse, mostrando a professora a efetuar uma viagem por mar para Banguecoque. Algum tempo depois, surge uma nova cena que perturba a ordem do filme, em que se vê três indivíduos da equipa de filmagens a conversar. Diz um: "too much a game. At least you should have a script", acrescentando outra: "and why the boy is crippled?" Este é um gesto de forte carga autorreflexiva, um momento em que os produtores encenam aperceber-se de que o seu filme poderá consistir apenas num jogo formal cuja narrativa não possui espessura (na opinião do primeiro falante, porque não há um guião). O exemplo, enquanto "falha", de não ter sido explicado o porquê de o rapaz estar preso a uma cadeira de rodas desencadeia a sequência seguinte, em que a equipa pede a uma jovem uma possível explicação para a existência da cadeira de rodas, num exercício de especulação interpretativa de uma história pré-existente que põe novamente em evidência o processo de feitura do filme.

A razão para a doença do rapaz é fornecida momentos mais tarde por uma mulher pertencente à equipa de filmagens: "I want the next sequence to be a flashback. There is a war going on in the background. The mother and the boy board the plane. But it is shot down, crashed. She is killed, but the boy survives. This is why the boy becomes crippled. Is it ok?" Ao proferir estas palavras, e ao seguir-se a esta cena uma outra ("cinematizada") que dela deriva, esta mulher está a executar algo semelhante ao que realizaram os narradores actantes: fornecer matéria linguística que o filme "cinematiza". A ingenuidade relativamente a essa "cinematização" que os outros possuíam, no entanto, é aqui inexistente, porque esta nova narradora não só é responsável pela história que conta como também o é pelo filme que se constrói. Ao contrário dos restantes, ela está a contar para o filme, daí a sua narração incluir terminologia fílmica, de "next sequence" a "flashback".

Do flashback passa-se para um outro tempo, presente, na diegese do "filme de ficção", em que acontecem duas situações relevantes: uma primeira em que, durante uma narração da professora ${ }^{5}$, uma referência à guerra ativa,

5 Uma narrativa sobre o seu passado, portanto ao nível das anteriores "histórias reais", 
no fluxo das imagens cinematográficas, cenas de destruição e guerra, resultando num gesto de fuga da ficção para imagens reais, de arquivo, que por isso mesmo se reportam tanto ao passado da personagem como de indivíduos reais, que sofreram, tal como ela, com essas imagens (reais) de guerra; e uma segunda, em que o processo de stop trick é usado, mostrando um rapaz a aparecer em campo magicamente, perturbando-se assim o tom naturalista que estava a ser trabalhado, numa confluência de duas tendências - a dos irmãos Lumière (naturalista, fotográfica) e de Méliès (fantasista) - que se prolongou, aliás, nos filmes subsequentes de Weerasethakul, e culminou porventura na absoluta naturalização do fantástico em Uncle Boonmee Who Can Recall His Past Lives (2010).

Após isto, a representação para, mas a câmara continua a filmar, o que resulta na revelação dos atores, que passam a ser actantes, numa nova problematização da relação ficção/documentário que deriva deste gesto de se passar da ficção ao documentário (ou não-ficção) sem que haja sequer corte na montagem, mas simplesmente a paragem da representação. $O$ ator jovem (o rapaz da cadeira de rodas) pergunta, a olhar para a câmara: "have you filmed?" E: “then it's the end? ${ }^{6}$ Let's go home." Nesta cena, o realizador Apichatpong Weerasethakul surge em campo a anunciar que terá de voltar a filmar a cena anterior (algo irónico, se se atentar que, no filme que vemos, a "cena anterior" e a cena presente correspondem a um único planosequência), pedindo para se alterar a iluminação do espaço, e depois a câmara filma os atores a lerem o que se supõe ser um guião. Um novo corte mostra a criança-ator a contar a sua história (das filmagens partirá para casa, para dar à avó o dinheiro que receberá pelo seu trabalho de ator); e se as narrações anteriores eram feitas nos tempos passado ou presente, a do rapaz é feita no tempo futuro.

Após alguns minutos de imagens contemplativas - às quais se voltará no final deste texto -, passa-se para o plano ficcional, sem que haja narração em voice over que o enquadre. Daí volta-se à narração, então efetuada por duas jovens mudas, em linguagem gestual com legendagem em tailandês a meio do campo, e, portanto, sobrepondo-se aos corpos das raparigas - algo usualmente evitado em legendagem de filmes, para obstruir o menos possível o

porém aqui "história real de personagem fictícia", isto é, "história dentro da história dentro da história" (cf. exemplos paradigmáticos deste tipo de construção: As mil e uma noites, de autor anónimo, e Manuscrit trouvé à Saragosse, de Jan Potocki, no qual se lê, a propósito deste fenómeno, o seguinte comentário irónico - porém apropriado à complexidade deste tipo de narrativas - elaborado por uma personagem: "Prestei muita atenção à narrativa do chefe, mas já não percebo nada: já não consigo saber quem fala ou quem escuta. Aqui, é o marquês de Val Florida que está a contar a sua história à filha, que a conta ao cigano, o qual, por sua vez, no-la conta a nós. É muito confuso. Sempre me pareceu que os romances e outras obras do género deviam ser escritos em várias colunas, como os tratados de cronologia." [Potocki, 2010: 396])

${ }^{6}$ Recorde-se que não é a primeira vez que um fim é anunciado durante o filme, evidenciando o seu caráter compósito, feito de partes que se articulam, no entanto diferenciadas e demarcadas. 
campo visual -, como se o filme procurasse dizer que a linguagem (agora visual, antes oral e escrita) é aqui (e, talvez, em todos os momentos de entrevistas) o foco principal, ou seja, neste passo específico, não interessa tanto ver as jovens mudas como ouvi-las (lê-las).

Surgem os últimos narradores, um grupo de crianças numa escola. Neste último segmento importa ressalvar vários aspetos, e o mais imediatamente aparente é a presença do microfone em campo sempre que se vê as crianças. Num filme em que, como visto, a relação entre o som e a imagem é desde o início problematizada, é relevante que, perto do final do filme, se faça notar a presença da captação de som, num reforço do artifício nas imagens documentais que, teoricamente, seriam as mais "puras". O que o filme vem dizendo é que nada, em cinema, é puro, mas tudo jogo, construção e necessariamente mediado pela tecnologia; nem mesmo as vozes que se ouvem são "naturais", como parecem ser, mas filtradas não só pelo dispositivo fílmico propriamente dito, como, antes disso, pelo microfone, num aumento dos níveis de diferimento.

Outro elemento importante deste último segmento é a natureza da narrativa fornecida. Se se disse antes que a primeira narradora construiu uma narrativa naturalista, à semelhança da sua história real, e que a segunda narradora contou uma narrativa fantástica, à semelhança da sua perceção falha da realidade, todas as narrações seguintes proporcionaram este tipo de paralelismos: os adolescentes e a vontade de viajar para Banguecoque, o grupo de atores e uma representação teatral que emprestou elementos burlescos à ficção de $M O A N$, a membro da equipa de filmagens que procurou "tapar os buracos" da narrativa que o seu filme contava, as jovens mudas e a amizade a surgir como elemento temático, etc. A história destas crianças é de cariz fantasista (com espadas mágicas, batalhas épicas, rapazes alienígenas), plena de reviravoltas inverosímeis, e adota ainda outra particularidade com que o filme joga inteligente e determinantemente: crianças irrequietas, rapidamente perderão o interesse nesta história e iniciarão outra. A certa altura, um rapaz diz: "that's the end", mas outra criança tem uma ideia, que era já impossibilitada pela narração anterior ${ }^{7}$. Depois disto, uma rapariga pergunta: "why not continue?", numa expressão clara e inocente do gosto de contar histórias apenas pelo prazer de contá-las". Daí parte-se para outra narrativa, a de uma Bruxa-Tigre que já nada tem que ver com toda a narrativa que $M O A N$ contou/mostrou.

O termo da história do rapaz da cadeira de rodas anuncia o fim do filme: enquanto as crianças contam a nova história, a câmara vagueia em travelling pelos espaços, até surgirem os créditos finais, seguindo-se-lhe um intertítulo que diz simplesmente “at noon”. Então, com o filme condenado pela

${ }^{7} \mathrm{O}$ rapaz deficiente acabara de morrer e ser cremado, mas agora um alienígena vem à Terra e cura as pernas do rapaz (que estaria morto e cremado), de modo a que este se possa vingar, derrotando o vilão e cedendo à história um happy end.

8 Algo que, grosso modo, poderia aplicar-se a Mysterious Object at Noon? 
conclusão da sua história, seguem-se cerca de seis minutos de imagem puramente contemplativa, agora sem narração alguma sobreposta. Este é um tipo de imagem que havia aparecido, a espaços, durante o filme, mas que nunca se conseguira fazer durar, porque a narração, significativamente, o interrompia sempre. Nestes minutos finais esse tipo de imagem impõe-se finalmente, e as vozes já nada dizem, e a linguagem (falada ou escrita) tornase ausente. Já não é exigido ao espectador qualquer gesto interpretativo. As imagens que então o filme oferece são autossuficientes na sua qualidade pictórica (unicamente "mostração" [showing], sem resquícios alguns de narração [telling $]^{\text {}}$ ), e o exercício que este propõe nesse momento talvez seja contrariamente ao que propusera durante quase toda a sua duração - de contemplação visual, sem necessidade do auxílio do filtro que é uma linguagem que, recorde-se, se impunha no início, ainda antes de haver imagem. Se o estímulo que todo o filme exercera até então havia sido essencialmente intelectual, neste momento parece ser puramente sensorial, como se, após o jogo da narração cessar, subsistisse o movimento perpétuo das imagens e fragmentos de histórias que acontecem no real sem necessitarem de ser contadas. Se inicialmente $M O A N$ apostara num modelo de cinema (meta)narrativo, fortemente apoiado na linguagem, esse modelo é, nos momentos finais, obliterado por este outro, que contaminaria de modo decisivo os filmes seguintes do realizador.

Compreender-se-á então, através desta análise, que Mysterious Object at Noon constitui um caso particularmente interessante enquanto filme inaugural de uma filmografia. A autorreflexividade com a qual o filme se vai construindo parece provir de um desejo quase obsessivo de explorar insistentemente diferentes modos de contar histórias em cinema. Como consequência, resulta talvez um filme sobre o qual se possa dizer com legitimidade que é "too much a game"; porém, se não se entender essa denominação como sendo pejorativa, descobre-se um filme que funciona perfeitamente como um "filme ensaio" sobre o cinema enquanto complexa máquina narrativa.

\section{Referências}

BORDWELL, David (2008). Narration in the Fiction Film. London: Routledge [1985].

CHION, Michel (2003). Un art sonore, le cinéma: histoire, esthétique, poétique. Paris: Cahiers du cinéma.

CHION, Michel (2007). Écrire un scénario. Paris: Cahiers du cinéma.

9 Ou, no binómio de Gaudreault: "monstration" e "narration" (Gaudreault, 2009: 7). Sobre "telling" e "showing", cf. também o capítulo "Mimetic Theories of Narration" no estudo seminal de David Bordwell, Narration in the Fiction Film (Bordwell, 2008: 315). 
COGHILL, Nevill (2003). In Geoffrey Chaucer, The Canterbury Tales. Trad. Nevill Coghill. London: Penguin.

CORRIGAN, Timothy (2011). The Essay Film: From Montaigne, After Marker. Oxford: Oxford University Press.

FLEISHMAN, Avrom (1992). Narrated Films: Storytelling Situations in Cinema History. London: Johns Hopkins University Press.

GAUDREAULT, André (2009). From Plato to Lumière: Narration and Monstration in Literature and Cinema. Trad. Timothy Barnard. Toronto: University of Toronto Press.

LOTHE, Jakob (2000). Narrative in Fiction and Film: An Introduction. Oxford: Oxford University Press.

POTOCKI, Jan (2010). Manuscrito Encontrado em Saragoça, Volume I. Trad. J. Espadeiro Martins. Lisboa: Cavalo de Ferro.

\section{Financiamento}

Artigo produzido no âmbito do projeto de investigação "Falso Movimento Estudos sobre Escrita e Cinema" (referência PTDC/CLE-LLI/120211/2010), Centro de Estudos Comparatistas da Faculdade de Letras da Universidade de Lisboa, financiado pela FCT - Fundação para a Ciência e a Tecnologia.

(C) 2013 José Bértolo. 